\title{
Ellipsis
}

2016

\section{Your Title Could Be Doing a Lot More}

Jessica Morey-Collins

Follow this and additional works at: https://scholarworks.uno.edu/ellipsis

\section{Recommended Citation}

Morey-Collins, Jessica (2016) "Your Title Could Be Doing a Lot More," Ellipsis: Vol. 43 , Article 11.

DOI: https://doi.org/10.46428/ejail.43.11

Available at: https://scholarworks.uno.edu/ellipsis/vol43/iss1/11

This Poetry is brought to you for free and open access by the Department of English and Foreign Languages at ScholarWorks@UNO. It has been accepted for inclusion in Ellipsis by an authorized editor of ScholarWorks@UNO.

For more information, please contact scholarworks@uno.edu. 


\title{
Your Title Could Be Doing a Lot More
}

\author{
Jessica Morey-Collins \\ Andrea Saunders Gereighty/Academy of American Poets Award Winner
}

Like whoring the poem out for a smidge of winter cozy

with some rich gentleman who has a whole hall of perfect tits

displayed at his vacation home (for skiing). Each lovely mound,

with its aptly sized nipple, is centered on a mahogany plaque - exactly

complemented to the plush green paint of the hallway walls, mahogany

plaque exactly matched to the mountain-lush paneling. Or, your title

could set the poem a quiver-like a perfect titted woman whose jiggles

are almost explosive in their perfection. Or, your title could trace a tit-

shape on a frost-covered window, for instance. Or for instance your title

could contradict itself, it could assess a flesh mound as both perfection

and not-perfection - the two concepts in perfect tension as pure

silliness, really, right? It's just fat under a nipple! your teenaged

self argues, before more fully exploring her bisexuality

and concluding that tits are a genuinely exceptional

good time.

Or maybe the title could take itself

for a nice, calming walk - after all, it's a lovely day, with winter just distant enough that all the nipples are hard but not yet diamond cutting or mythical skyward spires or hehe are you smuggling candies in your bra? Really, it's silly for your title to get so worked up about tits at all—don't you think? Even you, who's come to love them so voluptuously in all of their wild variety. Winter's been holding off a pinch longer this year, hovering like frost -glittering lips above a nipple. Maybe your title should stay in for the evening, get warm and clean for an earlier sleep. Maybe it should wash its own tits and swaddle them in pajamas. Anyway, if the poem quivered it would be more like a jello-mold than like a startled breast, I bet.

Maybe your title could forget about tits all-together. 